\title{
Experimental Investigation of the Inhibiting Action of Adenine on the Corrosion of Mild Steel in Acidic Environments
}

\author{
Habibat Momoh-Yahaya ${ }^{1}$, Nnabuk O. Eddy ${ }^{2}$, Johnson F. Iyun ${ }^{2}$, Casmir E. Gimba ${ }^{2} \&$ Emeka E. Oguzie $^{3}$ \\ ${ }^{1}$ Department of Chemistry, University of Agriculture Makurdi, Makurdi, Nigeria \\ ${ }^{2}$ Department of Chemistry, Ahmadu Bello University Zaria, Nigeria \\ ${ }^{3}$ Electrochemistry and Materials Science Research Laboratory, Department of Chemistry, Federal University of \\ Technology Owerri, Owerri, Nigeria
}

Correspondence: Habibat Momoh-Yahaya, Department of Chemistry, University of Agriculture Makurdi, P.M.B. 2373 Makurdi, Benue State, Nigeria. Tel: 234-807-357-7753. E-mail: momohbat2007@gmail.com

Received: September 18, 2012 Accepted: September 28, 2012 Online Published: November 15, 2012

doi:10.5539/jmsr.v2n1p59 URL: http://dx.doi.org/10.5539/jmsr.v2n1p59

\begin{abstract}
Corrosion inhibition of mild steel by adenine (AD) in $0.1 \mathrm{M}$ solutions of $\mathrm{HCl}$ and $\mathrm{H}_{2} \mathrm{SO}_{4}$ was investigated using weight loss, potentiodynamic polarization and electrochemical impedance spectroscopy techniques. The study was carried out at $30^{\circ} \mathrm{C}$ and $60^{\circ} \mathrm{C}$ respectively. The effect of iodide ions on inhibition efficiency was also assessed. Results showed that $\mathrm{AD}$ had a moderate inhibitive effect on the acid corrosion of mild in the order $\mathrm{HCl}>\mathrm{H}_{2} \mathrm{SO}_{4}$ at $30^{\circ} \mathrm{C}$ and $\mathrm{H}_{2} \mathrm{SO}_{4}>\mathrm{HCl}$ at $60^{\circ} \mathrm{C}$. The presence of iodide ions in the acid media increased the efficiency of $\mathrm{AD}$. From potentiodynamic polarization studies, it was observed that $\mathrm{AD}$ alone and the mixture of $\mathrm{AD}+\mathrm{KI}$ surpressed both the anodic and cathodic partial reactions. The corrosion processes were inhibited by adsorption of $\mathrm{AD}$ onto the mild steel surface in a concentration and temperature-dependent manner. Langmuir isotherm was used to explain the adsorptive characteristics of AD.
\end{abstract}

Keywords: acid solutions, EIS, inhibition efficiency, potentiodynamic polarisation

\section{Introduction}

Mineral acids find extensive applications in many industries: chemical, fertilizer, steel, mineral, water, oil, food, etc. (Dillon, 1994). The acidic properties of their ionized, aqueous solutions are due to the presence of hydrogen ion $\mathrm{H}^{+}$and its complexed form hydronium ion $\mathrm{H}_{3} \mathrm{O}^{+}$. The dissolution of metals in solutions of acids is a heterogeneous electrochemical reaction. Initially two phases coexist - a solid and a liquid, but as the reaction starts, a third phase appears - hydrogen gas, evolving from the metal surface. The kinetics of the dissolution process depends on the collision between the solvated protons and "active sites" on the metallic crystal surface; promoting anodic dissolution (Schorr et al., 2008; Sherif \& Park, 2006; Mattson \& Bockris, 1959). Hence, metal surfaces exposed to aqueous acidic environments are observed to undergo corrosion attack. The corrosion of mild steel in any given environment may proceed via different mechanisms and manifest in various forms. In a bid to reducing corrosion, some organic compounds called inhibitors are added to the agressive solution in contact with the metal surface thereby inhibiting corrosion and reducing the corrosion rate of the metal (Sastri, 1998).

Adenine is a purine reported to be a potential inhibitor for corrosion prevention of mild steel and copper in acid and neutral media (Scendo, 2007a, 2007b \& 2008; Amin et al., 2008; Yan et al., 2008). It is well known that the type of corrodent and metal, temperature of the understudy system as well as concentration and molecular structure of an inhibitor, are important factors for consideration in assessing the effectiveness of an inhibitor (Lashgari et al., 2010; Khaled, 2010; Oguzie, 2008; Eddy et al., 2010). The present study investigates the effect of type of acid anions on the corrosion inhibition potential of adenine in hydrochloric and sulphuric acid solutions. 


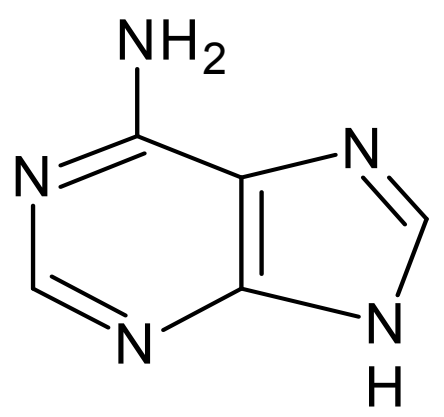

Figure 1. Molecular structure of adenine

\section{Experimental}

\subsection{Material}

Metal sheet of composition (wt.\%: Mn (0.6), P (0.36), C (0.15), Si (0.03) and the rest Fe) was used in this study. Acid solutions of $0.1 \mathrm{M} \mathrm{HCl}$ and $\mathrm{H}_{2} \mathrm{SO}_{4}$ were prepared by diluting analytical grades with distilled water. Solutions of the inhibitor were prepared at the concentration range $2.0 \times 10^{-3}-10.0 \times 10^{-3} \mathrm{M}$ in acid media. The effect of iodide ions on inhibition efficiency was studied at $30^{\circ} \mathrm{C}$ by combining $5.0 \times 10^{-3} \mathrm{M} \mathrm{KI}$. All reagents were obtained from Zayo-Sigma Chemicals. Figure 1 shows the molecular structure of adenine.

\subsection{Experimental Procedure}

\subsubsection{Weight Loss Measurements}

Mild steel coupons of dimension $5.0 \mathrm{~cm} \times 4.0 \mathrm{~cm} \times 0.15 \mathrm{~cm}$ were cut and wet-polished with silicon carbide abrasive paper (from grade \#400 to \#1000), rinsed with distilled water, dried in acetone and warm air, and weighed before immersion in the test solutions. The mild steel coupons were retrieved from the test solutions at $24 \mathrm{~h}$ progressively for $120 \mathrm{~h}$ at $30^{\circ} \mathrm{C}$ and $60^{\circ} \mathrm{C}$ respectively. The retrieved coupons were immersed in a $40 \%$ $\mathrm{NaOH}$ containing $100 \mathrm{gL}^{-1}$ of zinc dust, scrubbed using a bristle brush, rinsed with distilled water and ethanol, dried and re-weighed. All experiments were carried out in aerated solutions.

\subsubsection{Electrochemical Measurements}

Metal samples for electrochemical experiments were machined into test electrodes of dimension $1 \times 1 \mathrm{~cm}^{2}$ and sealed with epoxy resin in such a way that only one square surface area $\left(1 \mathrm{~cm}^{2}\right)$ was left uncovered. The exposed surface was cleaned using the procedure described above. Electrochemical tests were conducted in a Model K0047 corrosion cell using a VERSASTAT 400 complete DC voltammetry and corrosion system, with V3 Studio software. A graphite rod was used as a counter electrode and a saturated calomel electrode (SCE) as a reference electrode. The latter was connected via a Luggin capillary. Measurements were performed in aerated and unstirred solutions at the end of $1 \mathrm{~h}$ of immersion at $30^{\circ} \mathrm{C}$. Impedance measurements were made at corrosion potentials $\left(\mathrm{E}_{\text {corr }}\right)$ over a frequency range of $100 \mathrm{KHz}-10 \mathrm{MHz}$, with a signal amplitude perturbation of $5 \mathrm{mV}$. Potentiodynamic polarization studies were carried out in the potential range $\pm 250 \mathrm{mV}$ versus corrosion potential at a scan rate of $0.33 \mathrm{mV} / \mathrm{s}$. Each test was run in triplicate.

\section{Results and Discussion}

\subsection{Weight Loss Measurements}

\subsubsection{Weight Losses and Corrosion Rates of Mild Steel}

The rates of mild steel corrosion in $0.1 \mathrm{M}$ solutions of hydrochloric and sulphuric acid at 30 and $60^{\circ} \mathrm{C}$ are shown in Figure 2. The plots represent the results obtained for a 5-day immersion period. The results obtained show that $\mathrm{AD}$ manifested a higher inhibiting effect on mild steel in $\mathrm{HCl}$ at $30^{\circ} \mathrm{C}$ and in $\mathrm{H}_{2} \mathrm{SO}_{4}$ at $60^{\circ} \mathrm{C}$. This is an evidence that the degree of protonation as well as nature of the acid anions influence the corrosion process (Lashgari et al., 2010; Oguzie, 2008).

The corrosion rate, $\mathrm{CR} \mathrm{gcm}^{-2} \mathrm{~h}^{-1}$, as a function of exposure time was calculated using the equation (Eddy et al., 2010):

$$
C R\left(g h^{-1} \mathrm{~cm}^{-2}\right)=\frac{\Delta W}{A t}
$$


where $\Delta \mathrm{W}$ is the weight loss in $\mathrm{g}, \mathrm{A}$ is the exposed area of the coupon $\left(\mathrm{in}^{2} ; 1 \mathrm{in}^{2}=6.5146 \mathrm{~cm}^{2}\right)$ and $\mathrm{T}$ is the immersion time (h). The results obtained are presented in Table 1.

Figure 3 reveals the corrosion-inhibiting effect of AD on the corrodents, which becomes more pronounced with increasing $\mathrm{AD}$ concentration, implying a dependence of the inhibition process on the amount of the inhibiting species present in the system. Again, the plots suggest that not only the inhibitory power of AD increases with concentration but the performance also is a function of the acid type and temperature.

The inhibition efficiency (IE\%) of AD in the acid media was calculated using the equation (Eddy et al., 2010):

$$
\mathrm{IE} \%=\left(1-\frac{\Delta \mathrm{W}_{\text {inh }}}{\Delta \mathrm{W}_{\text {blank }}}\right) \mathrm{X} 100
$$
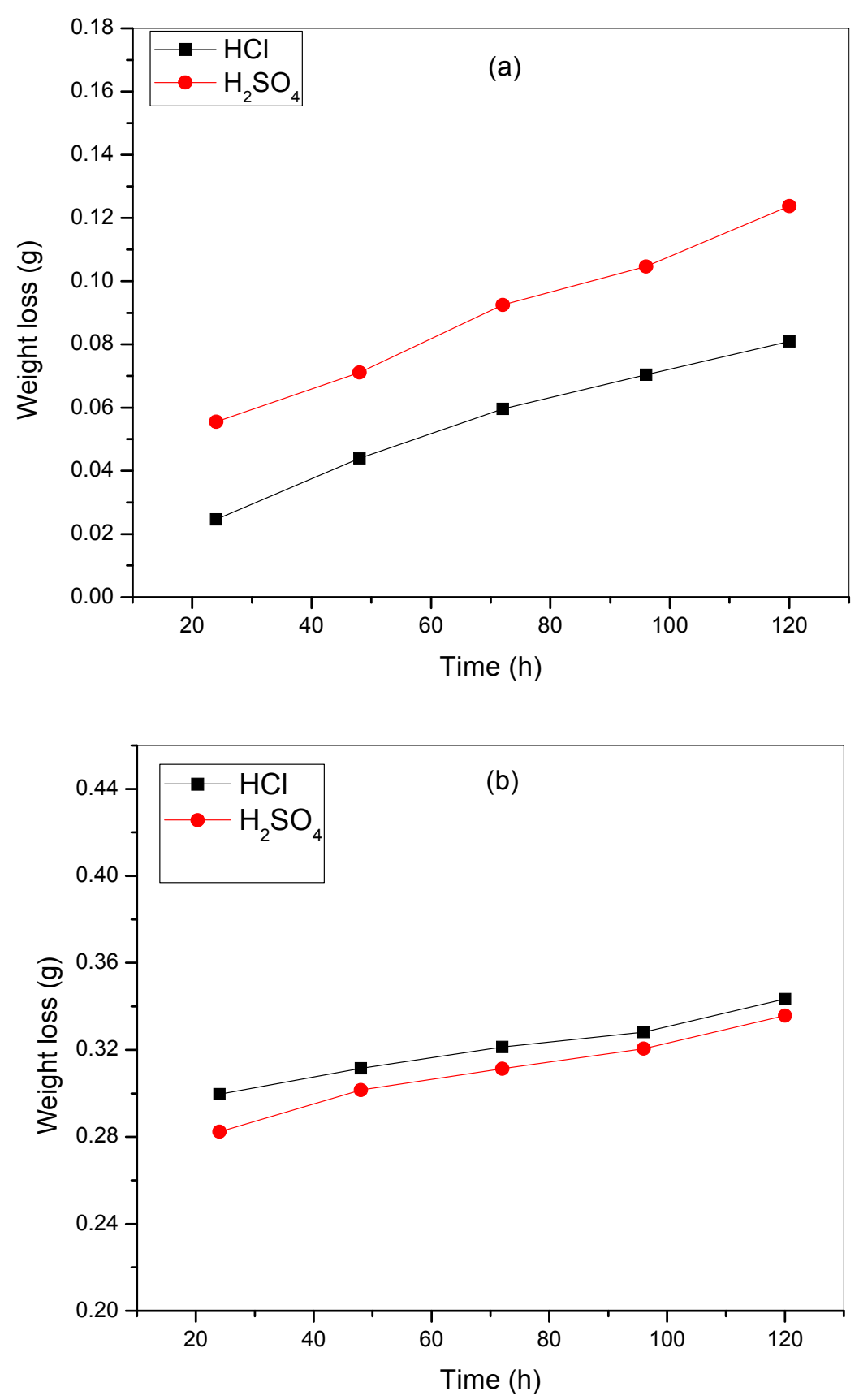

Figure 2. Weight losses of mild steel in $0.1 \mathrm{M}$ solutions of $\mathrm{HCl}$ and $\mathrm{H}_{2} \mathrm{SO}_{4}$ as a function of immersion time at (a) $30^{\circ} \mathrm{C}$ and (b) $60^{\circ} \mathrm{C}$ 

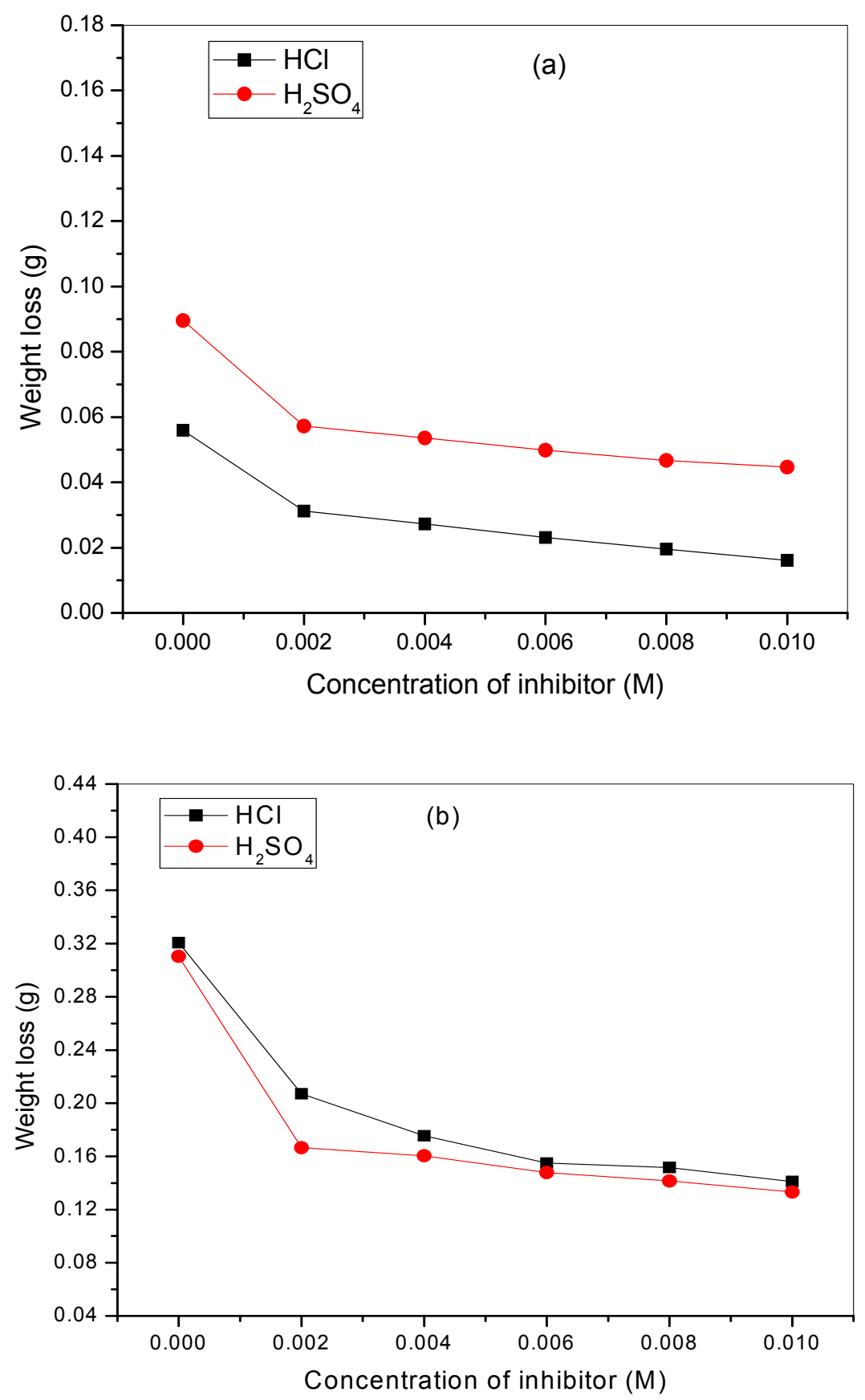

Figure 3. Weight losses of mild steel in $0.1 \mathrm{M}$ solutions of $\mathrm{HCl}$ and $\mathrm{H}_{2} \mathrm{SO}_{4}$ without and with different concentrations of $\mathrm{AD}$ at (a) $30^{\circ} \mathrm{C}$ and (b) $60^{\circ} \mathrm{C}$ 
Table 1. Weight loss data for mild steel in $0.1 \mathrm{M}$ solutions of $\mathrm{HCl}$ and $\mathrm{H}_{2} \mathrm{SO}_{4}$ in the absence and presence of various concentrations of $\mathrm{AD}$ at $30^{\circ} \mathrm{C}$ and $60^{\circ} \mathrm{C}$ respectively

\begin{tabular}{|c|c|c|c|c|c|}
\hline \multirow[t]{2}{*}{$\mathrm{T}^{\circ} \mathrm{C}$} & \multirow[t]{2}{*}{ Concentration (M) } & \multicolumn{2}{|c|}{ Corrosion rate $\mathrm{x} 10^{-4}\left(\mathrm{gh}^{-1} \mathrm{~cm}^{-2}\right)$} & \multicolumn{2}{|c|}{ Inhibition Efficiency (\% } \\
\hline & & $\mathrm{HCl}$ & $\mathrm{H}_{2} \mathrm{SO}_{4}$ & $\mathrm{HCl}$ & $\mathrm{H}_{2} \mathrm{SO}_{4}$ \\
\hline \multirow{6}{*}{30} & Blank & 1.16 & 1.86 & - & - \\
\hline & 0.002 & 0.65 & 1.19 & 44.18 & 36.09 \\
\hline & 0.004 & 0.56 & 1.12 & 51.34 & 40.11 \\
\hline & 0.006 & 0.48 & 1.04 & 58.68 & 44.36 \\
\hline & 0.008 & 0.40 & 0.97 & 65.11 & 47.82 \\
\hline & 0.01 & 0.33 & 0.93 & 71.20 & 50.06 \\
\hline \multirow{6}{*}{60} & Blank & 6.68 & 6.46 & - & - \\
\hline & 0.002 & 4.31 & 3.47 & 35.47 & 46.34 \\
\hline & 0.004 & 3.66 & 3.34 & 45.26 & 48.28 \\
\hline & 0.006 & 3.23 & 3.08 & 51.68 & 52.34 \\
\hline & 0.008 & 3.16 & 2.95 & 52.71 & 54.37 \\
\hline & 0.01 & 2.94 & 2.78 & 56.05 & 57.04 \\
\hline
\end{tabular}

\subsection{Electrochemical Measurements}

Impedance and potentiodynamic polarization tests were undertaken at $30^{\circ} \mathrm{C}$ to study the inhibiting effect of $\mathrm{AD}$ on the electrochemical corrosion behavior of mild steel in the acid media. The optimum concentration of $0.01 \mathrm{M}$ AD was used for the electrochemical measurements.

\subsubsection{Potentiodynamic Polarization Data}

Polarization measurements were undertaken to investigate the the behaviour of mild steel electrodes in $0.1 \mathrm{M}$ solutions of $\mathrm{HCl}$ and $\mathrm{H}_{2} \mathrm{SO}_{4}$ in the absence and presence of $\mathrm{AD}$. The current - potential relationship for the mild steel electrode at various test solutions is shown in Figures 4-5, while the electrochemical data obtained from the polarization curves are summarized in Table 2.

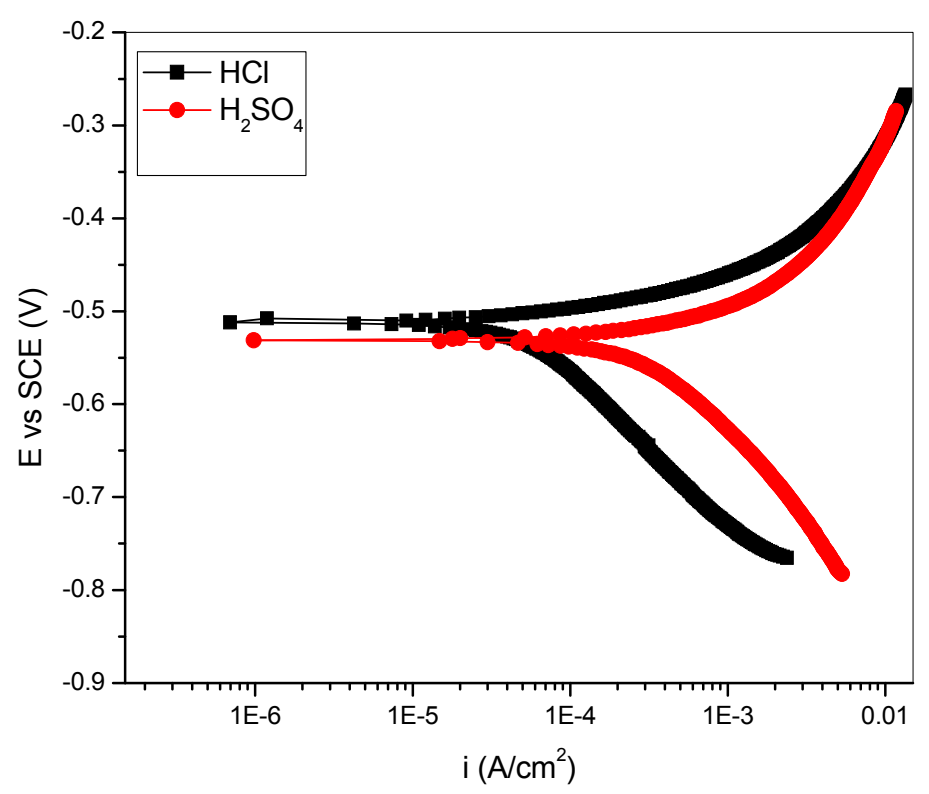

Figure 4. Potentiodynamic polarisation curves of mild steel in $0.1 \mathrm{M}$ solutions of $\mathrm{HCl}$ and $\mathrm{H}_{2} \mathrm{SO}_{4}$ 

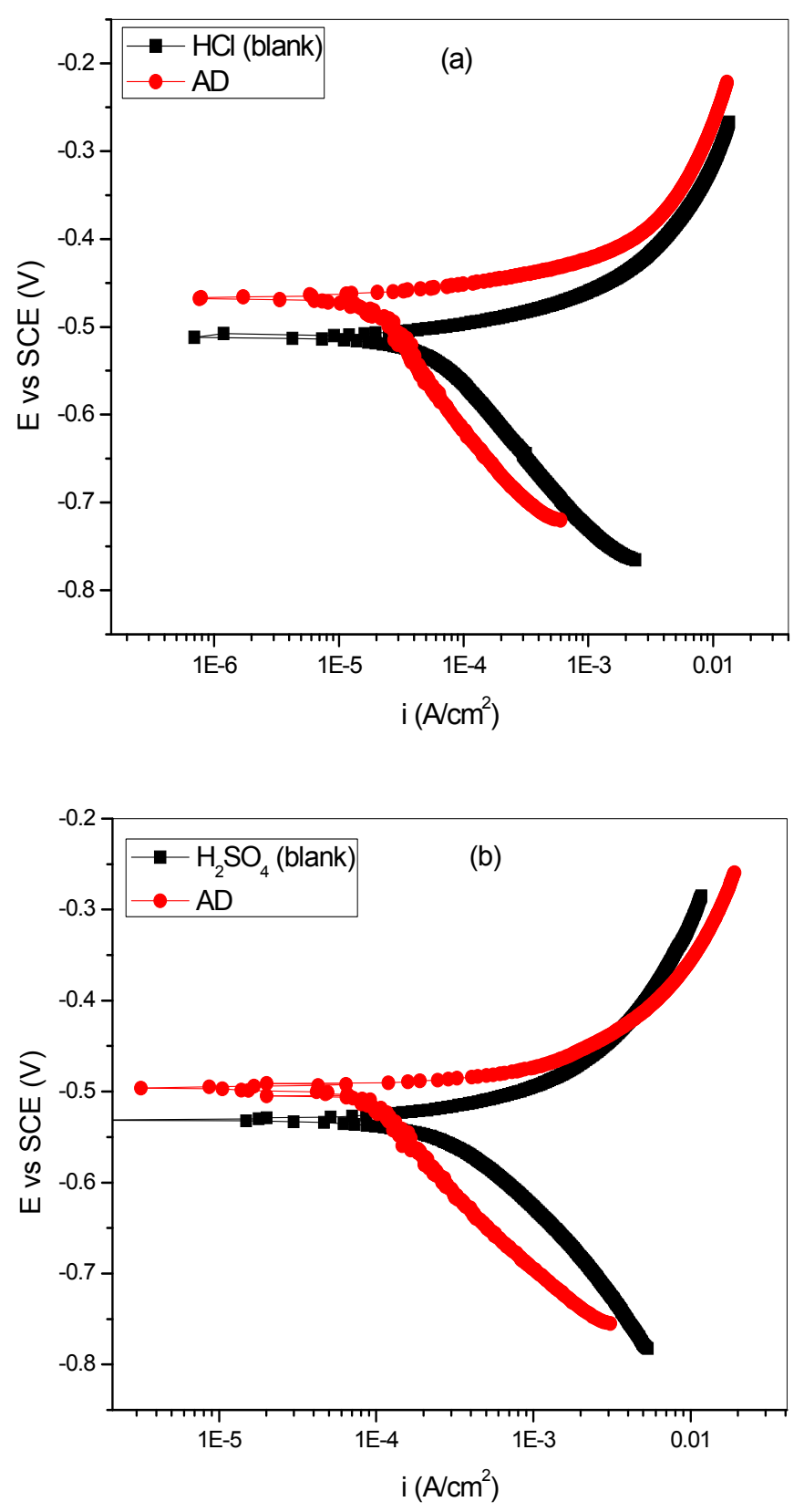

Figure 5. Potentiodynamic polarization curves of mild steel in the absence and presence of $\mathrm{AD}$ in $0.1 \mathrm{M}$ solutions of (a) $\mathrm{HCl}$ and (b) $\mathrm{H}_{2} \mathrm{SO}_{4}$

Addition of $\mathrm{AD}$ is seen to affect the anodic as well as the cathodic partial reactions, shifting the corrosion potential $\left(\mathrm{E}_{\mathrm{corr}}\right)$ toward more positive (anodic) values and reducing the anodic and cathodic current densities and the corresponding corrosion current density ( $\left.\mathrm{i}_{\text {corr }}\right)$. The shift in $\left(\mathrm{E}_{\text {corr }}\right)$ was profound in both $\mathrm{HCl}$ and $\mathrm{H}_{2} \mathrm{SO}_{4}$ systems. This indicates that AD functioned as a mixed-type inhibitor in the acid solutions (Scendo, 2007a, 2007b $\&$ 2008; Amin et al., 2008; Yan et al., 2008). The values of corrosion current densities in the absence ( $\left.i_{\text {corr }}\right)$ and presence of inhibitor $\left(i_{\text {inh }}\right)$ were used to estimate the inhibition efficiency from polarization data $\left(\mathrm{IE}_{\mathrm{i}} \%\right)$ as follows:

$$
I E_{i} \%=\left(1-\frac{i_{\text {inh }}}{i_{\text {corr }}}\right) \times 100
$$

The obtained values are presented in Table 2 . 
Table 2. Polarization data for mild steel in $0.1 \mathrm{M}$ solutions of $\mathrm{HCl}$ and $\mathrm{H}_{2} \mathrm{SO}_{4}$ in the absence and presence of $\mathrm{AD}$

\begin{tabular}{cccc}
\hline System & $\mathrm{E}_{\text {corr }}(\mathrm{mV}$ vs SCE $)$ & $\mathrm{i}_{\text {corr }}\left(\mu \mathrm{A} / \mathrm{cm}^{2}\right)$ & $\mathrm{IE} \%$ \\
\hline $\mathrm{HCl}($ Blank $)$ & -512.13 & 173.1 & \\
$\mathrm{AD}(0.01 \mathrm{M})$ & -468.23 & 52.10 & 69.90 \\
$\mathrm{H}_{2} \mathrm{SO}_{4}$ (Blank) & -528.64 & 212.35 & \\
$\mathrm{AD}(0.01 \mathrm{M})$ & -499.10 & 114.39 & 46.13 \\
\hline
\end{tabular}

\subsubsection{Electrochemical Impedance Spectroscopy}

Nyquist plots show single semicircles for all systems over the frequency range studied (Figures 6-7). The high frequency intercept with the real axis in the Nyquist plots is assigned to the solution resistance $\left(R_{s}\right)$ and the low frequency intercept with the real axis is ascribed to the charge transfer resistance $\left(\mathrm{R}_{\mathrm{ct}}\right)$. The impedance spectra were analyzed by fitting to the equivalent circuit model $R_{s}\left(Q_{d l} R_{c t}\right)$ (Oguzie et al., 2009; Oguzie et al., 2010). In this equivalent circuit, the solution resistance is shorted by a constant phase element (CPE) that is placed in parallel to the charge transfer resistance. The CPE is used in place of a capacitor to compensate for deviations from ideal dielectric behavior arising from the inhomogeneous nature of the electrode surfaces. The impedance of the CPE is given by

$$
Z_{C P E}=Q^{-1}(j \omega)^{-n}
$$

where $Q$ and $n$ stand for the CPE constant and exponent respectively, $j=(-1)^{1 / 2}$ is an imaginary number, and $\omega$ is the angular frequency in $\mathrm{rad} \mathrm{s}^{-1}(\omega=2 \pi \mathrm{f})$, where $\mathrm{f}$ is the frequency in $\mathrm{Hz}$.

The corresponding electrochemical parameters are given in Table 3 and show that the presence of AD increased the magnitude of $R_{c t}$, with corresponding decrease in the double layer capacitance $\left(Q_{d 1}\right)$. The increase in $R_{c t}$ values in inhibited systems which correspond to an increase in the diameter of the Nyquist semicircle, confirms the corrosion inhibiting effect of $\mathrm{AD}$. The observed decrease in $\mathrm{C}_{\mathrm{dl}}$ values, which normally results in the double-layer thickness can be attributed to the adsorption of $\mathrm{AD}$ (with lower dielectric constant compared to the displaced adsorbed water molecules) onto the mild steel/acid interface, thereby protecting the metal from corrosion.

Inhibition efficiency from the impedance data was estimated by comparing the values of the charge transfer resistance in the absence $\left(\mathrm{R}_{\mathrm{ct}}\right)$ and presence of inhibitor $\left(\mathrm{R}_{\mathrm{ct}, \mathrm{inh}}\right)$ as follows:

$$
I E \%=\left(\frac{R_{c t(i n h)}-R_{c t}}{R_{c t(i n h)}}\right) \times 100
$$

The magnitude and trend of the obtained values presented in Table 3 agree with those determined from gravimetric and polarization measurements. 


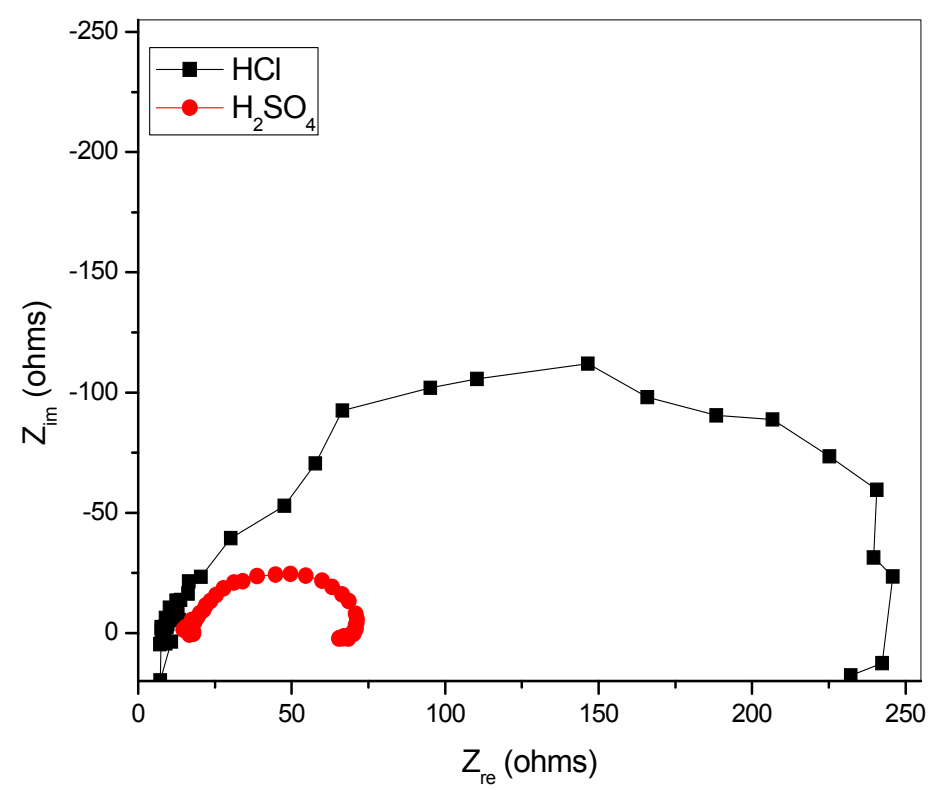

Figure 6. Electrochemical impedance spectra of mild steel in $0.1 \mathrm{M}$ solutions of $\mathrm{HCl}$ and $\mathrm{H}_{2} \mathrm{SO}_{4}$

Table 3. Electrochemical impedance data for mild steel in $0.1 \mathrm{M}$ solutions of $\mathrm{HCl}$ and $\mathrm{H}_{2} \mathrm{SO}_{4}$ in the absence and presence of $\mathrm{AD}$

\begin{tabular}{ccccc}
\hline System & $\mathrm{R}_{\mathrm{ct}}\left(\Omega \mathrm{cm}^{2}\right)$ & $\mathrm{C}_{\mathrm{dl}}\left(\mu \Omega^{-1} \mathrm{~S}^{\mathrm{n}} \mathrm{cm}^{-2}\right)$ & $\mathrm{N}$ & $\mathrm{IE} \%$ \\
\hline $\mathrm{HCl}($ Blank $)$ & 231.4 & 3.5 & 0.87 & - \\
$\mathrm{AD}(0.01 \mathrm{M})$ & 698.6 & 0.39 & 0.82 & 66.88 \\
$\mathrm{H}_{2} \mathrm{SO}_{4}$ (Blank) & 62.56 & 5.9 & 0.88 & - \\
$\mathrm{AD}(0.01 \mathrm{M})$ & 115.4 & 2.7 & 0.84 & 45.79 \\
\hline
\end{tabular}

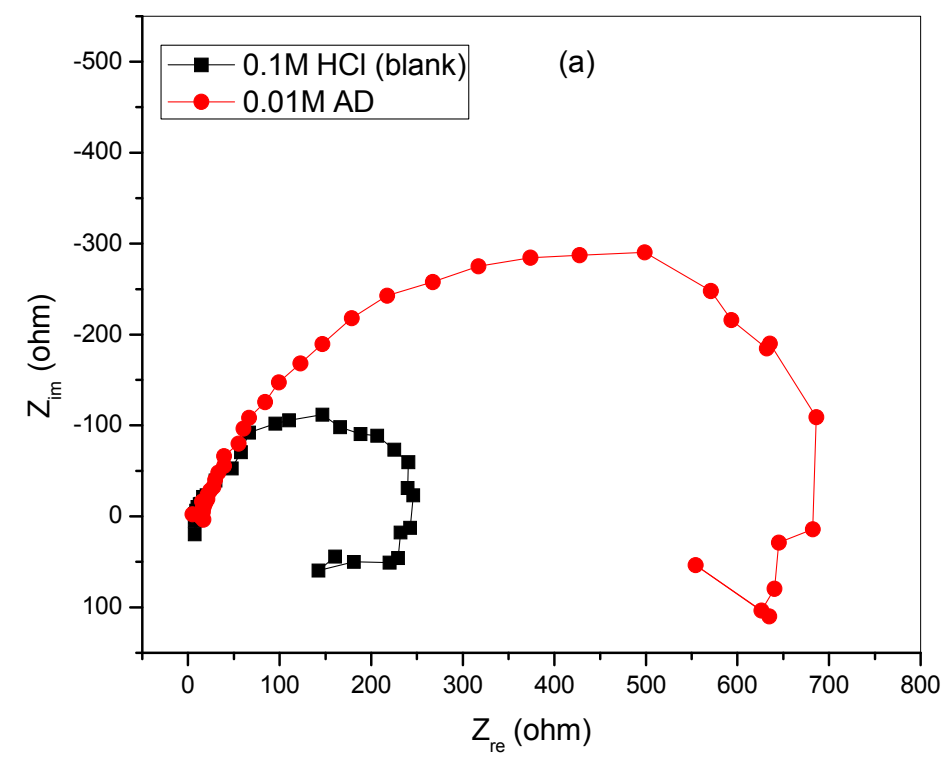




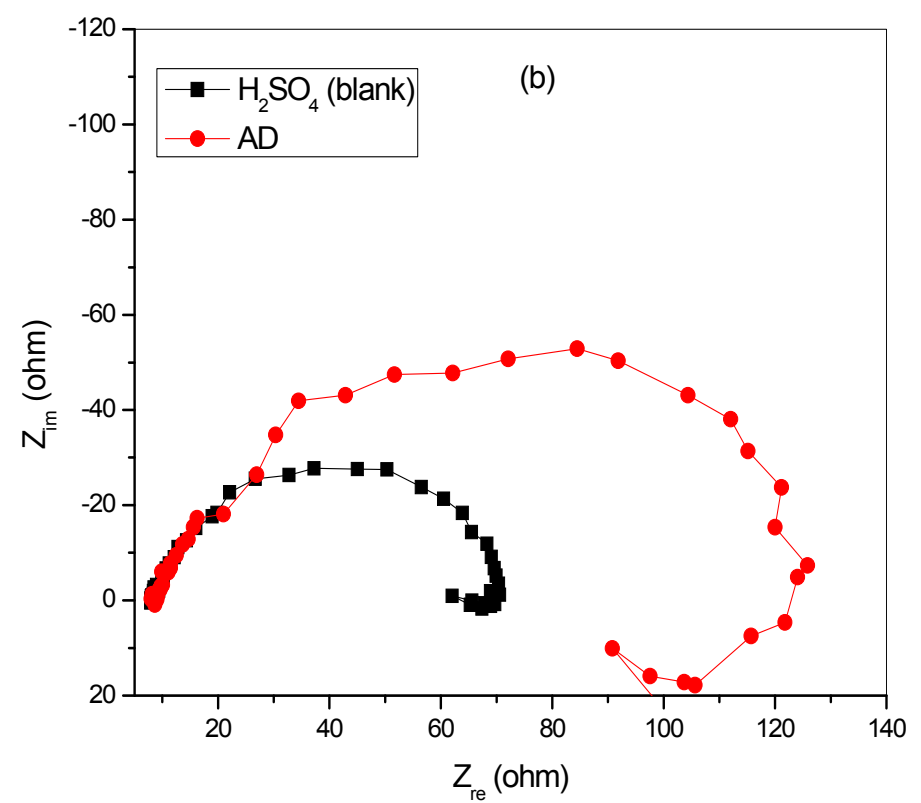

Figure 7. Electrochemical impedance spectra of mild steel in the absence and presence of $0.01 \mathrm{M} \mathrm{AD}$ in $0.1 \mathrm{M}$ solutions of (a) $\mathrm{HCl}$ and (b) $\mathrm{H}_{2} \mathrm{SO}_{4}$

\subsubsection{Synergistic Considerations}

It has been reported that $\mathrm{AD}$ is an organic base which depending on its $\mathrm{pH}$, can be present in aqueous solutions as protonated cationic species, neutral molecules, or dissociated anionic species. The protonated AD then exists in equilibrium with the molecular form. Literature reports reveal that the protonated cationic forms are more in solution in the $\mathrm{pH}$ range $0-2$ while the neutral molecules of $\mathrm{AD}$ are the dominant species at $\mathrm{pH}$ range 5-9 (Scendo, 2007; Amin et al., 2008; Katritzky, 1984).

The influence of $0.005 \mathrm{M} \mathrm{KI}$ on the corrosion of mild steel in $0.1 \mathrm{M} \mathrm{HCl}$ and $\mathrm{H}_{2} \mathrm{SO}_{4}$ containing $0.01 \mathrm{M} \mathrm{AD}$, corresponding to $[\mathrm{KI}] /[\mathrm{AD}]$ ratio of 0.5 , is depicted in Figure $8 \mathrm{a}$ by polarization. The addition of KI produce more effects on the anodic and cathodic currents in both $\mathrm{HCl}$ and $\mathrm{H}_{2} \mathrm{SO}_{4}$ solutions than those displayed by $\mathrm{AD}$ alone, shifting $E_{\text {corr }}$ in the anodic direction. Also, the corrosion current density decreases substantially, leading to higher inhibition efficiency in $\mathrm{HCl}$ and $\mathrm{H}_{2} \mathrm{SO}_{4}$ as follows: $79.50 \%$ and $88.68 \%$, compared to $69.90 \%$ and $46.13 \%$ respectively obtained for $\mathrm{AD}$ alone. This indicates a synergistic effect between $\mathrm{AD}$ and KI. Synergistic effects are also revealed in the impedance spectra obtained for mild steel on addition of $0.005 \mathrm{M} \mathrm{KI}$ to $0.1 \mathrm{M} \mathrm{HCl}$ and $\mathrm{H}_{2} \mathrm{SO}_{4}$ solutions containing $0.01 \mathrm{M}$ AD. The results illustrated in Figure 9, show that the presence of KI increased the diameters of the semicircles in the Nyquist plots and as well introduced an inductive element at low frequencies in the impedance response. The large high frequency capacity loop reflects further increase in the resistance to the charge transfer process of the reaction, including formation of a more compact inhibitor layer. The low frequency inductive behaviour may be as a result of bulk or surface relaxation processes due to the adsorption of intermediate products on the oxide film covering the electrode surface.

Corrosion inhibition synergism results from increased surface coverage arising from ion-pair interactions between the organic AD cations and the iodide ions (Oguzie, 2004). The different acid anions might however compete with iodide ions for active sites on the metal surface leading to a lower synergistic effect depending on the $\mathrm{pH}$ of the bulk solution and that which is obtainable at the metal/acid interface. However, our results indicate that the presence of some specifically adsorbed iodide ions enhanced adsorption of AD cations and hence augmented the inhibition efficiency in $\mathrm{H}_{2} \mathrm{SO}_{4}$ and slightly in $\mathrm{HCl}$. The inhibition efficiency values obtained from the different techniques are listed in Table 4 and show close similarities. 

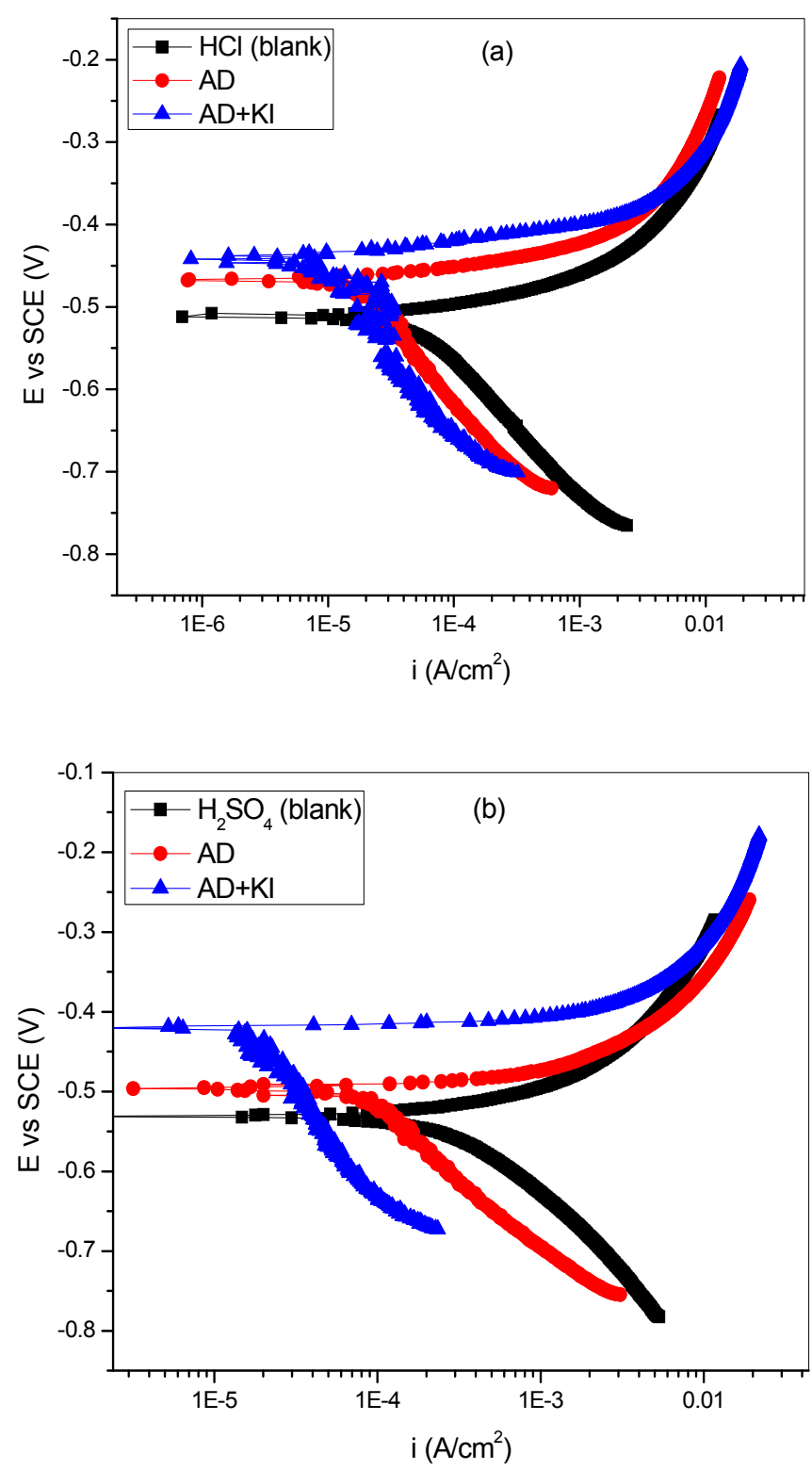

Figure 8. Potentiodynamic polarisation curves of mild steel in $0.1 \mathrm{M}$ solutions of (a) $\mathrm{HCl}$ and (b) $\mathrm{H}_{2} \mathrm{SO}_{4}$ without and with $\mathrm{AD}$ and $\mathrm{AD}+\mathrm{KI}$ 

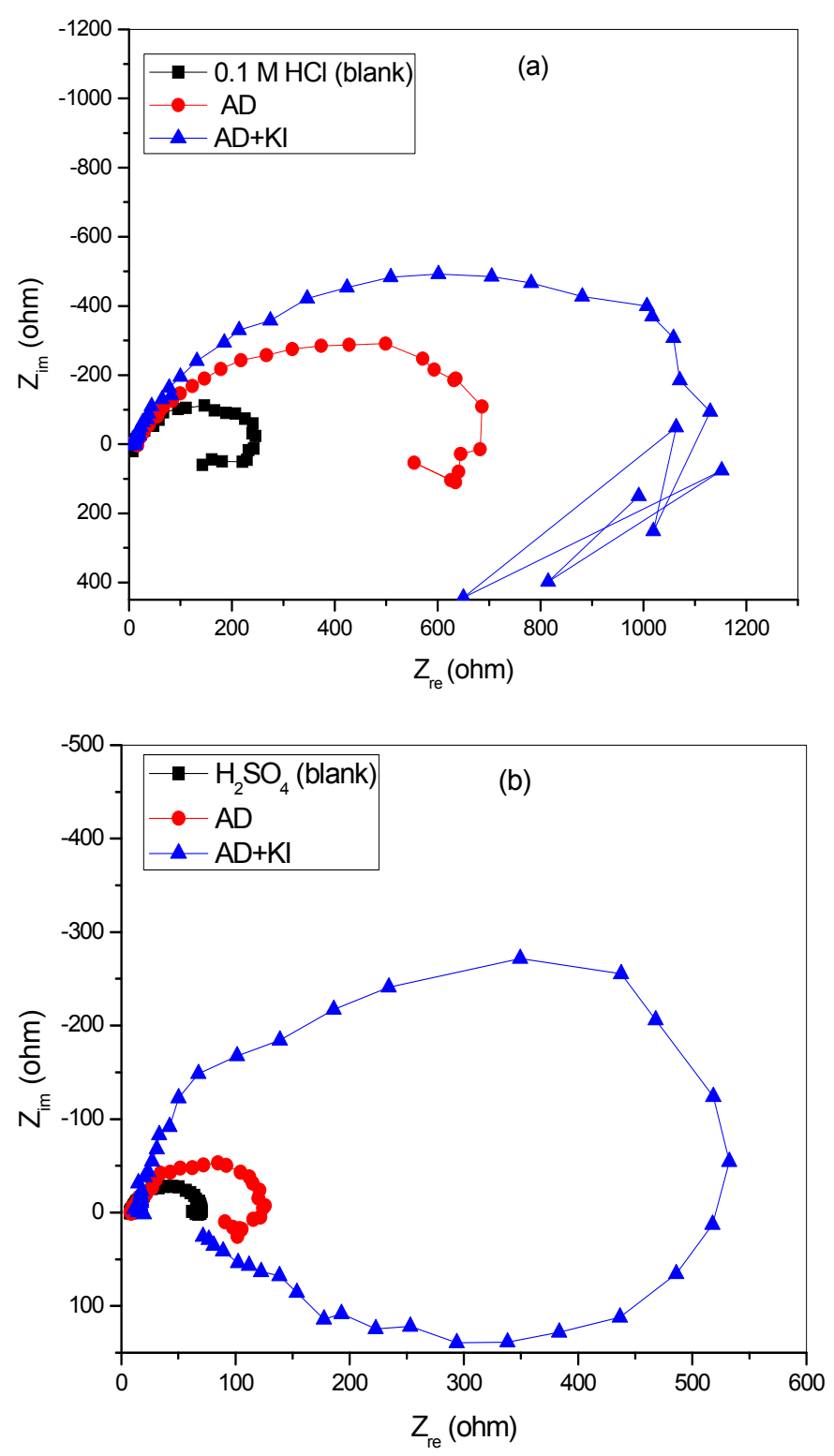

Figure 9. Electrochemical impedance spectra of mild steel in $0.1 \mathrm{M}$ solutions of (a) $\mathrm{HCl}$ and (b) $\mathrm{H}_{2} \mathrm{SO}_{4}$ without and with $\mathrm{AD}$ and $\mathrm{AD}+\mathrm{KI}$ 

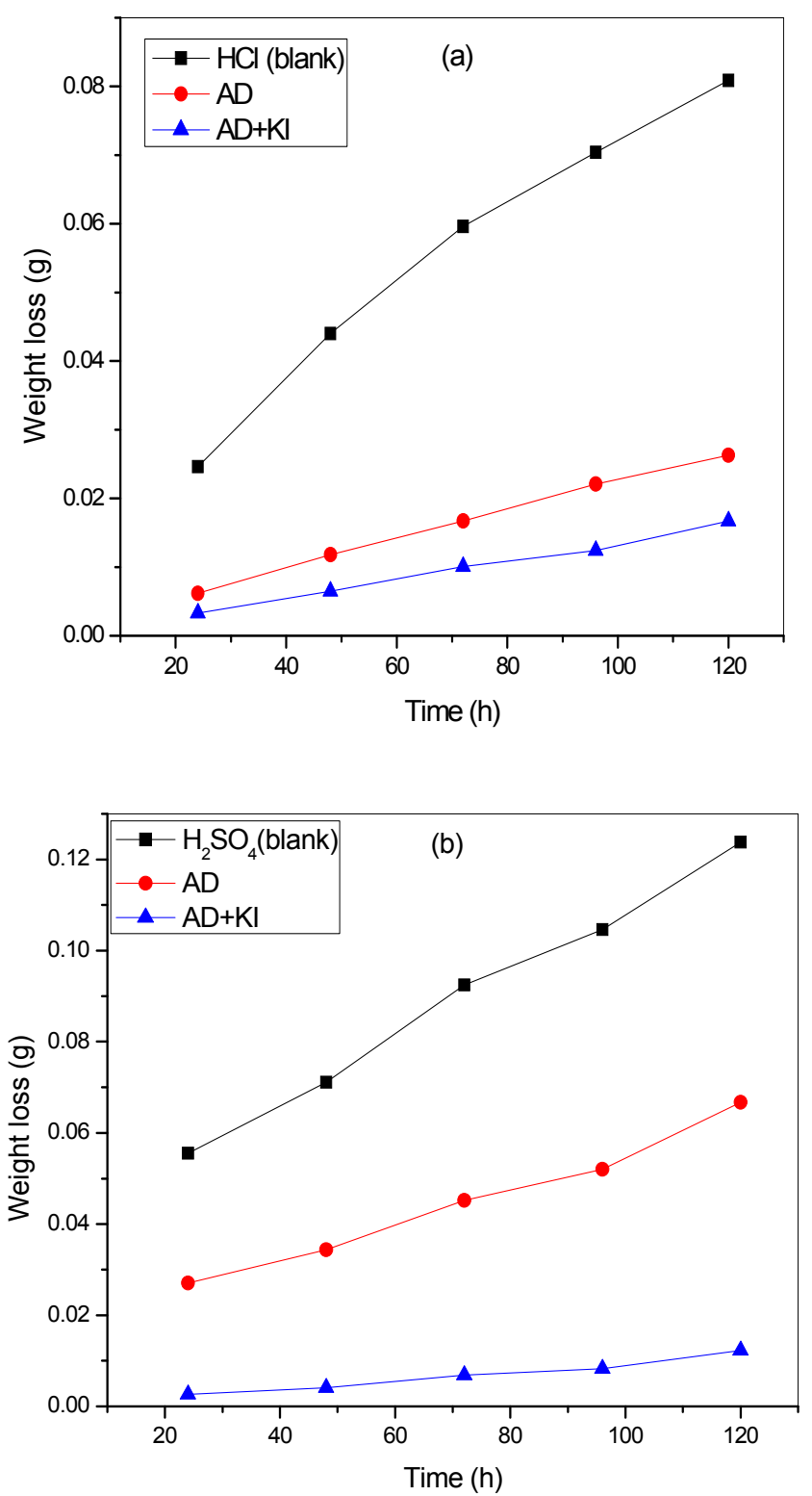

Figure 10. Weight losses of mild steel against immersion time in $0.1 \mathrm{M}$ solutions of (a) $\mathrm{HCl}$ and (b) $\mathrm{H}_{2} \mathrm{SO}_{4}$ without and with $\mathrm{AD}$ and $\mathrm{AD}+\mathrm{KI}$

Table 4. Inhibition efficiencies from $0.01 \mathrm{M} \mathrm{AD}$ in $0.1 \mathrm{M}$ solutions of $\mathrm{HCl}$ and $\mathrm{H}_{2} \mathrm{SO}_{4}$ in the presence of 0.005 M KI

\begin{tabular}{cccc}
\hline \multirow{2}{*}{ System } & \multicolumn{3}{c}{ Inhibition Efficiency (\%) } \\
\cline { 2 - 4 } & Weight loss & Polarization & Impedance \\
\hline $\mathrm{HCl}$ & & & \\
$\mathrm{AD}+\mathrm{KI}$ & 80.40 & 79.50 & 79.20 \\
$\mathrm{H}_{2} \mathrm{SO}_{4}$ & & & \\
$\mathrm{AD}+\mathrm{KI}$ & 87.50 & 88.68 & 88.35 \\
& & & \\
\hline
\end{tabular}




\subsection{Thermodynamics and Adsorption Considerations}

The specific mechanism by which an inhibitor reacts with the surface of a metal is a function of the type and composition of metal, corrosive agent, inhibitor structure and concentration, and temperature of the system under investigation. The adsorption mechanism of $\mathrm{AD}$ on mild steel was investigated by changing the temperature of the systems from $30^{\circ} \mathrm{C}$ to $60^{\circ} \mathrm{C}$. The trend in inhibition efficiency against temperature is shown in Table 1 . The apparent activation energies $\left(E_{a}\right)$ for the corrosion process in absence and presence of $A D$ were calculated using a modified form of the Arrhenius equation:

$$
\log \frac{\rho_{2}}{\rho_{1}}=\frac{E_{a}}{2.303 R}\left(\frac{1}{T_{1}}-\frac{1}{T_{2}}\right)
$$

Where $\rho_{1}$ and $\rho_{2}$ are the corrosion rates at temperatures $T_{1}$ and $T_{2}$, respectively. The heats of adsorption $\left(Q_{\text {ads }}\right)$ was quantified from the trend of surface coverage with temperature as follows (Bhajiwala \& Vashi, 2001):

$$
Q_{a d s}=2.303 R\left[\log \left(\frac{\theta_{2}}{1-\theta_{2}}\right)-\log \left(\frac{\theta_{1}}{1-\theta_{1}}\right)\right] \times \frac{T_{1} T_{2}}{T_{2}-T_{1}}
$$

where $\theta_{1}$ and $\theta_{2}$ are the degrees of surface coverage at temperatures $T_{1}$ and $T_{2}$, and $R$ is the gas constant. The calculated values for both parameters are given in Table 5. The values reveal that inhibition efficiency increased with rise in temperature in $0.1 \mathrm{M} \mathrm{H}_{2} \mathrm{SO}_{4}, \mathrm{E}_{\mathrm{a}}$ in the presence of $\mathrm{AD}$ was lower than that in the uninhibited acid. The positive values of $\mathrm{Q}_{\mathrm{ads}}$ implies an increase in degree of surface coverage with rise in temperature, indicative of chemisorption. The decrease in inhibition efficiency with increase in temperature for $\mathrm{AD}$ in $\mathrm{HCl}$ as well as a negative $Q_{\text {ads }}$ values suggests physisorption and also signifies that the degree of surface coverage decreased with rise in temperature, $\mathrm{E}_{\mathrm{a}}$ tend to decrease on addition of $\mathrm{AD}$ to mild steel in $\mathrm{HCl}$ solution. The reason for this, as suggested by Oguzie (Oguzie, 2004) may be that equilibrium is rapidly attained in physical adsorption resulting in desorption whereas in chemisorptions, the process is relatively slow and not readily reversible.

Langmuir isotherm best describes the adsorption of AD onto the mild steel surface(Figure 11). Linear plots were obtained with deviations of the slope from unity while correlation coefficients $\left(\mathrm{R}^{2}\right)$ obtained from the plots were greater than 0.98 at both temperatures. This implies that the isotherm may not be strictly applicable. Similar results have been reported by other authors (Yan et al., 2008; Oguzie, 2004 \& 2008; Umoren, 2009).

Langmuir isotherm is given by (Lebrini et al., 2006):

$$
\frac{C}{\theta}=\frac{1}{K_{a d s}}+C
$$

Table 5. Activation energy $\left(\mathrm{E}_{\mathrm{a}}\right)$ and heat of adsorption $\left(\mathrm{Q}_{\mathrm{ads}}\right)$ for mild steel dissolution in $0.1 \mathrm{M}$ solutions of $\mathrm{HCl}$ and $\mathrm{H}_{2} \mathrm{SO}_{4}$ in the absence and presence of $\mathrm{AD}$ at 30 and $60^{\circ} \mathrm{C}$ respectively

\begin{tabular}{lllll}
\hline Concentration $(\mathrm{M})$ & \multicolumn{2}{c}{$\mathrm{E}_{\mathrm{a}}(\mathrm{KJ} / \mathrm{mol})$} & \multicolumn{2}{c}{$\Delta \mathrm{Q}_{\text {ads }}(\mathrm{KJ} / \mathrm{mol})$} \\
\cline { 2 - 5 } & $\mathrm{HCl}$ & $\mathrm{H}_{2} \mathrm{SO}_{4}$ & $\mathrm{HCl}$ & $\mathrm{H}_{2} \mathrm{SO}_{4}$ \\
\hline Blank & 49.01 & 34.86 & & \\
0.002 & 52.96 & 29.96 & -3.86 & 4.49 \\
0.004 & 52.23 & 30.59 & -2.58 & 3.51 \\
0.006 & 53.32 & 30.40 & -3.00 & 3.39 \\
0.008 & 57.45 & 30.96 & -5.46 & 2.78 \\
0.01 & 60.81 & 30.63 & -7.00 & 2.97 \\
\hline
\end{tabular}



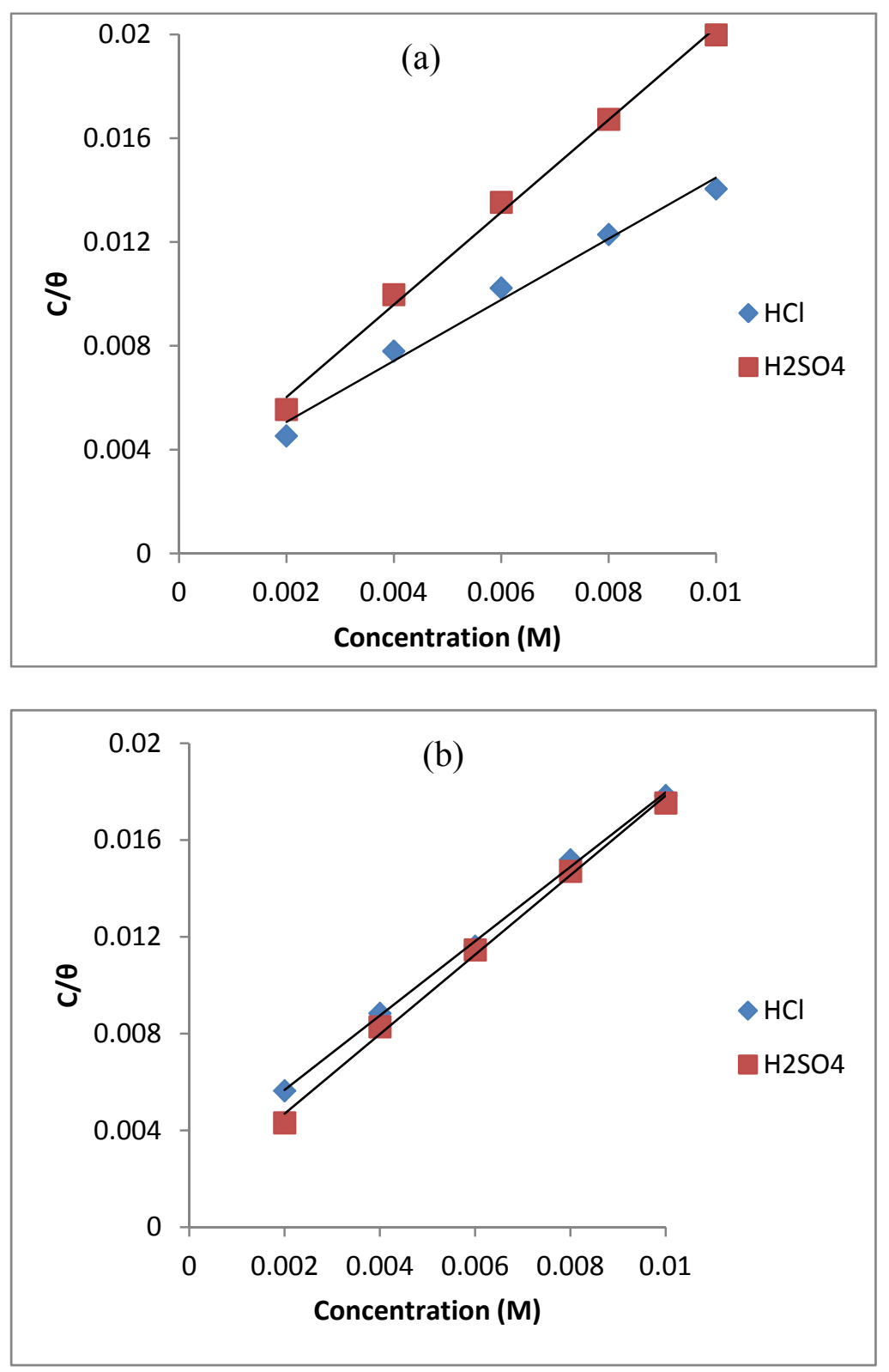

Figure 11. Langmuir isotherm for the adsorption of $\mathrm{AD}$ in $0.1 \mathrm{M}$ solutions of $\mathrm{HCl}$ and $\mathrm{H}_{2} \mathrm{SO}_{4}$ at (a) $30^{\circ} \mathrm{C}$ and (b) $60^{\circ} \mathrm{C}$

Table 6. Thermodynamic parameters from Langmuir adsorption isotherm

\begin{tabular}{ccccccc}
\hline Temperature ${ }^{\circ} \mathrm{C}$ & System & Intercept & Slope & $\mathrm{K}_{\text {ads }}\left(\mathrm{M}^{-1}\right)$ & $\mathrm{R}^{2}$ & $\Delta \mathrm{G}_{\text {ads }}^{\circ}(\mathrm{kJ} / \mathrm{mol})$ \\
\hline 30 & $\mathrm{HCl}$ & 0.002 & 1.176 & 500 & 0.984 & -25.78 \\
& $\mathrm{H}_{2} \mathrm{SO}_{4}$ & 0.002 & 1.781 & 500 & 0.995 & -25.78 \\
\hline & $\mathrm{HCl}$ & 0.002 & 1.537 & 500 & 0.998 & -28.33 \\
60 & $\mathrm{H}_{2} \mathrm{SO}_{4}$ & 0.001 & 1.643 & 1000 & 0.996 & -30.25 \\
\hline
\end{tabular}

\section{Conclusion}

Results obtained from the study show that $\mathrm{AD}$ inhibited the corrosion of mild steel in $0.1 \mathrm{M}$ solutions of $\mathrm{HCl}$ and $\mathrm{H}_{2} \mathrm{SO}_{4}$. The presence of iodide ions enhanced the inhibitive behaviour of $\mathrm{AD}$ in both $\mathrm{HCl}$ and $\mathrm{H}_{2} \mathrm{SO}_{4}$ systems. Protonated and neutral species of $\mathrm{AD}$ are proposed to be responsible for the observed inhibitive behaviour of $\mathrm{AD}$ 
in $\mathrm{HCl}$ and $\mathrm{H}_{2} \mathrm{SO}_{4}$ respectively. Polarization measurements suggest a mixed-inhibition mechanism, which the impedance data indicate was achieved via adsorption of the species on the carbon steel surface.

\section{Acknowledgements}

Facilities for the weight loss experiments were provided by the Kaduna Refinery and Petrochemicals Company (KRPC), Nigeria. The authors acknowledge financial support by TWAS, the Academy of Sciences for the Developing World, under the TWAS GRANTS for Research Units in Developing Countries Program (TWASRGA08-005). H. Momoh-Yahaya is grateful to the Educational Trust Fund (ETF), Nigeria, for staff training grant.

\section{References}

Amin, M. A., Mohsen, Q., \& Hazzazi, O. A. (2008). Synergistic effect of $\mathrm{I}^{-}$ions on the corrosion inhibition of Al in $1.0 \mathrm{M}$ phosphoric acid solutions by purine. Mater. Chem. and Phys. http://dx.doi.org/10.1016/j.matchemphys.2008.10.057

Bhajiwala, H. M., \& Vashi, R. T. (2001). Ethanolamine, diethanolamine and triethanolamine as corrosion inhibitors for zinc in binary acid mixture [HNO3+H3PO(4)]. Bull. Electrochem. Soc., 17, 441-448.

Dillon, C. P. (1994). Corrosion Control in the Chemical Process Industries (2nd ed.), MTI.

Eddy, N. O., Ebenso, E. E., \& Ibok, U. J. (2010). Adsorption, synergistic inhibitive effect and quantum chemical studies on ampicillin and halides for the corrosion of mild steel. J. Appl. Electrochem, 40, 445-456. $\mathrm{http} / / / \mathrm{dx}$. doi.org/10.1007/s10800-009-0015-z

Katritzky, A. R. (1984). Comprehensive Heterocyclic Chemistry, The structure, reaction, synthesis and uses of heterocyclic compounds (vol. 5). London: Pergamon Press Ltd.

Khaled, K. F. (2010). Studies of iron corrosion inhibition using chemical, electrochemical and computer simulation techniques. Electrochim. Acta, 55, 6523-6532. http://dx.doi.org/10.1016/j.electacta.2010.06.027

Lashgari, M., Arshadi, M. R., \& Biglar, M. J. (2010). Experimental and theoretical studies of media effects on copper corrosion in acidic environments containing 2-amino-5-mercapto-1,3,4-thiadiazole. Iran. Chem. Soc., 7, 478-486.

Lebrini, M., Bentiss, F., Vezin, H., \& Lagrenee, M. (2006). The inhibition of mild steel corrosion in acidic solutions by 2,5-bis(4-pyridyl)-1,3,4-thiadiazole: structure-activity correlation. Corros. Sci., 48(5), 1279-1291. http://dx.doi.org/10.1016/j.corsci.2005.05.001

Mattson, E., \& Bockris, J. O. M. (1959). Galvanostatic studies of the kinetics of deposition and dissolution in the copper + copper sulphate system. Trans. Faraday Soc., 55, 1586-1601. http://dx.doi.org/10.1039/tf9595501586

Oguzie, E. E. (2004). Influence of halide ions on the inhibitive effect of congo red dye on the corrosion of mild steel in sulphuric acid solution. Mater. Chem. Phys., 87, 212-217. http://dx.doi.org/10.1016/j.matchemphys.2004.06.006

Oguzie, E. E. (2008). Corrosion inhibitive effect and adsorption behaviour of Hibiscus sabdariffa extract on mild steel in acidic media. Port. Electrochim. Acta., 26, 303-314. http://dx.doi.org/10.4152/pea.200803303

Oguzie, E. E., Enenebeaku, C. K., Akalezi, C. O., Okoro, S. C., Ayuk, A. A., \& Ejike, E. N. (2010). Adsorption and corrosion inhibiting effect of Dacryodis edulis extract on low carbon steel corrosion in acidic media. $J$. Colloid Interface Sci., 349, 283-292. http://dx.doi.org/10.1016/j.jcis.2010.05.027

Oguzie, E. E., Wang, S. G., Li Y., \& Wang, F. H. (2009). Influence of iron microstructure on corrosion inhibitor performance in acidic media. J. Phys. Chem. C., 113, 8420-8429. http://dx.doi.org/10.1021/jp9015257

Sastri, V. S. (1998). Corrosion Inhibitors: Principles and Applications. New York, NY: John Wiley \& Sons Ltd.

Scendo, M. (2007a). The effect of purine on the corrosion of copper in chloride solutions. Corros. Sci., 49, 373-390. http://dx.doi.org/10.1016/j.corsci.2006.06.022

Scendo, M. (2007b). Inhibitive action of purine and adenine for copper corrosion in sulphate solutions. Corros. Sci., 49, 2985-3000. http://dx.doi.org/10.1016/j.corsci.2007.01.002

Scendo, M. (2008). The influence of adenine on corrosion of copper in chloride solutions. Corros. Sci., 50, 2070-2077. http://dx.doi.org/10.1016/j.corsci.2008.04.007

Schorr, M., Valdez, B., Stoytcheva, M., \& Zlatev, R. (2008). Kinetics and structure aspects of the dissolution of 
metals in acids. ECS Trans., 13(27), 143-150. http://dx.doi.org/10.1149/1.3040298

Sherif, E. M., \& Park, S. M. (2006). Inhibition of copper corrosion in acidic pickling solutions by $N$-phenyl-1,4 phenylenediamine. Electrochim. Acta, 51, 4665-4673. http://dx.doi.org/10.1016/j.electacta.2006.01.007

Umoren, S. A., Li, Y., \& Wang, F. H. (2010). Electrochemical study of corrosion inhibition and adsorption behaviour for pure iron by polyacrylamide in $\mathrm{H}_{2} \mathrm{SO}_{4}$ : Synergistic effect of iodide ions. Corros. Sci., 52(5), 1777-1786. http://dx.doi.org/10.1016/j.corsci.2010.01.026

Yan, Y., Weihua, L., Lankun, C., \& Baorong, H. (2008). Electrochemical and quantum chemical study of purines as corrosion inhibitors for mild steel in $1 \mathrm{M} \mathrm{HCl}$ solution. Corros. Sci., 53, 5953-5960. 